\title{
MORPHOLOGICAL FEATURES OF SARMATIAN POPULATION OF THE LOWER VOLGA REGION ACCORDING TO THE DATA OF OSTEOLOGICAL ANALYSIS ${ }^{1}$
}

\section{Elena Gennadyevna Zubareva}

Archaeology Expert, "Arkheologicheskoe obshchestvo Kubani” OJSC elena_lisa89@mail.ru

Prosp. Chekhova, 62/5, 344006 Rostov-on-Don, Russian Federation

\begin{abstract}
The article discusses the history of studies on the anthropological and osteological material of the Early Iron Age Sarmatians of the Lower Volga region. The author investigates the 81 male and 70 female osteological samples of early Sarmatians from the Lower Volga region. The article contains the general characteristics of the sampling, the intra-group analysis, the description of physical types peculiar for Sarmatian men and women.

The heterosexual groups of early Sarmatians of the Lower Volga region have the following characteristics: the absolute values of the transverse dimensions in men and women are characterized by overall averages, which indicate elongation. The longitudinal indicators in men and women are biased to larger values. Early Sarmatians are also characterized by local differences that are exemplified by the series from the Volga-Don interfluve and the Trans-Volga region. The intergroup analysis allows establishing the similarity between the studied samples and that of Southern Siberia. This fact proves the migrational conception of Sarmatians origin. Association of early Sarmatians of the Lower Volga region with a group of Tagantsev, as well as with middle and late Sarmatians of the Saratov Trans-volga region, is explainable as their partial genetic match can be observed through the craniological features.
\end{abstract} analysis.

Key words: Early Iron Age, Lower Volga Region, osteometry, method of principal components, intergroup

\section{МОРФОЛОГИЧЕСКИЕ ОСОБЕННОСТИ САРМАТСКОГО НАСЕЛЕНИЯ НИЖНЕГО ПОВОЛЖЬЯ ПО ДАННЫМ ОСТЕОЛОГИЧЕСКОГО АНАЛИЗА ${ }^{1}$}

\section{Елена Геннадьевна Зубарева}

Специалист-археолог, ООО «Археологическое общество Кубани»

elena_lisa89@mail.ru

просп. Чехова, 62, к. 5, 344006 г. Ростов-на-Дону, Российская Федерация 
Аннотация. В работе рассмотрена история изучения антропологического материала раннего железного века. Исследована остеологическая выборка ранних сармат в Нижнем Поволжье - 81 мужского и 70 женских индивидов. Дана общая характеристика мужской и женской выборок, проведен внутригрупповой анализ, выделены физические типы, характерные для мужского и женского населения. Проведен межгрупповой анализ, благодаря которому удалось установить, что исследуемая выборка тяготеет к южносибирсим выборкам, что подтверждает миграционную концепцию происхождения сарматов.

Ключевые слова: ранний железный век, Нижнее Поволжье, остеометрия, метод главных компонент, межгрупповой анализ.

Сарматы - собирательное название, которым сперва древнегреческие, а затем древнеримские историки и географы называли различные племена, которые населяли степи Евразии от Монголии до Дуная. Савромато-сарматское население со сложной этнической историей и многоукладной культурой около тысячи лет проживало на территории Нижнего Поволжья. Контакты кочевого сарматского населения стали освещаться в письменных источниках на рубеже эр. Однако сведения античных авторов зачастую отрывочны, и достаточно глубоко изучать историю сарматов только по данным письменных свидетельств не представляется возможным.

Проследить этногенез сарматской культуры помогают археологические и антропологические исследования материалов, которые стали регулярно добываться в нашем регионе с середины сороковых годов XX века. Увеличение археологического материала позволяет ученым заниматься разработкой проблем истории сарматов региона более глубоко. Особое место в сарматологии занимает вопрос о становлении различных стадий сарматской культуры. В литературе появляются уточнения датировок стадий сарматской эпохи, данной впервые с привычными нам названиями К.Ф. Смирновым и Б.Н. Граковым. В последнее время возникла острая дискуссия по вопросу этнической принадлежности сарматских культур, разрабатываются характеристики сарматской культуры на основе локальных вариантов.

В специальной научной антропологической литературе достаточно материалов, освещающих антропологическую принадлежность древнего населения Нижнего Поволжья. В основном антропологические исследования проводились на основе краниологических измерений с незначительным привлечением остеологического материала, в то время как для исследований физического типа сарматского населения, для по- строений этногенетических реконструкций важны и остеометрические измерения. Остеометрия позволяет проследить изменчивость телосложения древних групп во времени и пространстве. Кости посткраниального скелета используются для реконструкции длины тела, восстановления пропорций, соотношения отдельных сегментов конечностей и др.

Одна из первых работ, в которой рассматривается антропологический материал из раннесарматских погребений, была написана С.И. Руденко [18]. Костный материал происходил из погребений прохоровских и покровских курганов. Именно в этом труде ученый впервые дал описание антропологичекого типа сарматов, определив его как вариант широкоголовых европеоидов.

Во второй половине $\mathrm{XX}$ в. начинается активное изучение антропологии сарматских культур. К концу 40-х гг. Г.Ф. Дебец [12] выделяет две локальные группы сарматов. К сожалению, ученый рассматривал суммарную серию без культурного деления. Вместе с тем четко выделяется группа ранних сарматов из могильника Батаевка, которая диагностируется как тип широкоголовых европеоидов.

Крупную серию из 72 черепов Калиновского могильника исследовал В.В. Гинзбург [11]. Весь костный материал сарматской эпохи им был дифференцирован согласно культурной принадлежности. Ключевые выводы сводятся к следующему: 1) основным расовым типом у сарматов является европеоидный, долихомезокранный с малонаклонным лбом, среднеразвитым переносьем и надбровными дугами, узким и низким лицом, низкими глазницами и резко выступающим носом; 2) сарматы Сталинградского Заволжья представляют собой в основном два древних гиперморфных типа: протоевропеоидный и андроновский; 3 ) население было смешанным, смешение происходило постоянно, а не в какой-то определенный период [11, с. 574]. 
В 1968 г. М.С. Акимовой были опубликованы три серии черепов IV-III вв. до н. э. из могильника Мечет-Сай, Новый Кумак и Старые Киишки. Автор считает, что эти приуральские могильники оставлены разными по физическому типу населением [1, с. 41]. Новокумакская серия отличается от Мечетсайской некоторым увеличением высотных признаков лицевого скелета. Кроме того, лицо у них уже сильнеепрофилировано в горизонтальной плоскости, переносье тоже высокое. Морфологические особенности мечетсайкой выборки заключаются в малой величине высоты черепного свода.

В дальнейшем изучением сарматской антропологии занималась Б.В. Фирштейн. В своей работе «Сарматы Нижнего Поволжья. Антропологический аспект» [20] Б.В. Фирштейн приходит к следующим выводам:

1. Сарматы Саратовского Заволжья относятся к большой европеоидной расе. Лоб у них широкий, средненаклонный. Лицо ортоганное, умеренно профилированное по горизонтали. Нос во всех случаях сильно выступает. Это люди среднего роста с крепким телосложением.

2. На полученном материале удалось выделить черепа с чертами большой монголоидной расы и смешанных монголоидно-европеоидных метисов.

3. Среди мужских черепов преобладает андроновский тип, а среди женских - тип среднеазиатского междуречья.

4. Обнаружив близость всех региональных групп сарматов между собой, Б.В. Фирштейн пришла к выводу, что антропологический тип сарматов сложился еще в «савроматскую» эпоху.

5. Видимо, к среднесарматскому времени сохраняется часть субстратного раннесарматского населения, что отражается в сходстве раннесарматского и среднесарматского населения.

6. Межгрупповые сопоставления свидетельствуют о морфологической близости сарматов к синхронному населению Предгорного Алтая. Генетические корни сарматов, по мнению автора, происходят из среды племен, населявших Поволжье и Казахстан в эпоху бронзы.

Статья Е.Ф. Батиевой посвящена сарматам Маныч-Сальского междуречья [8]. Серия представлена 70 черепами раннесармат- ской и среднесарматской культур. Обе мужские мезокранные. Лицо в горизонтальной плоскости очень хорошо профилировано. Отмечен большой процент низколицых черепов. Максимальное сходство сарматы Маныч-Сальского междуречья обнаруживают с савроматами сарматской группы. Отличаются они от всех ранее опубликованных сарматов более резкой горизонтальной профилировкой.

Фундаментальное исследование всего сарматского и, в частности, раннесарматского материала осуществлено М.А. Балабановой. Впервые М.А. Балабанова предприняла расчленение раннесарматского антропологического материал на две группы $[3 ; 4 ; 5 ; 7]$.

В результате исследования выяснилось, что антропологический состав ранних сарматов IV-III вв. до н. э. Нижнего Поволжья складывается из двух резко различающихся между собой краниотипов. Один из них массивный, с крупной брахикранной мозговой коробкой, широким, покатым и резко профилированным лбом. Морфологичекие особенности этого типа предполагают наличие монголоидных черт. Другой - грацильный - насыщен, наоборот, европеоидным комплексом, тоже брахикранный и низкосводный, но гораздо мельче, чем первый [6, с. 71-72].

Заселение сарматами Нижнего Поволжья и Волго-Донского междуречья осуществлялось посредством миграций с территории Южного Приуралья. У ранних сарматов III-I вв. до н. э. в Заволжье формируется краниотип, который в той или иной степени объединяет все локальные выборки этого времени [4, с. 84].

Впоследствии, к рубежу эр, раннесарматское общество приняло очередную группу мигрантов, которыебыли носителями новых культурных традиций. Однако смена одной сарматской культуры другой не связана с полной сменой населения и угратой культурных ценностей [7, с. 187].

По мнению М.А. Балабановой, основные положения по происхождению ранних сарматов IV-III вв. до н. э. заключаются в следующем:

1. В формировании антропологического облика ранних сарматов IV-III вв. до н. э. активно участвовало население Южного Приуралья и Нижнего Поволжья.

2. Савроматы были не только их непосредственными предками, но и близкими родственниками. 
При рассмотрении локальной изменчивости раннесарматских серий выявляется ее клинальный характер как в ранней группе, так и в поздней. При этом более широкоголовые с низким сводом и широким лицом сарматы жили в восточных регионах, а альтернативные им типы - в Волго-Донском междуречье. Такое распределение изменчивости может быть свидетельством связи ранних сарматов с европейскими скифами [4].

Что же касается демографии ранних сарматов, то М.А. Балабановой выделяется различный демографический статус ранней IVIII вв. до н. э. и III-I вв. до н. э. В курганных группах почти отсутствуют детские погребения и гораздо меньше женских погребений, чем мужских [4, с. 85].

Подробное изучение патологии ранних сарматов осуществлено Е.В. Перервой в своей диссертационной работе. Рассматривая особенности раннесарматских костяков, он сделал ряд выводов, связанных со спецификой хозяйственной деятельности и образом жизни.

Ранние сарматы Нижней Волги и Нижнего Дона характеризуются как кочевникискотоводы с высоким уровнем развития военного дела. Сарматские племена активно взаимодействовали друг с другом, с соседними кочевыми и оседлыми племенами, и это взаимодействие часто носило агрессивный характер: имели место разбои, грабежи, военные походы, отразившиеся в виде маркеров физиологического стресса и травм различного характера. Автор говорит о том, что очень часто встречается зубной камень, который определяет характер их питания, связанный с мясомолочной диетой. Для них также были характерны длинные периоды голодания, распространены хронические заболевания, которые, вероятно, обострялись во время зим, особенно в течение ряда засушливых лет, сопровождавшихся падежом скота $[17$, с. $12-13]$.

Исследования остеологических серий ведутся с начала XX века. В отечественной антропологической науке сложилось так, что система остеометрических признаков не получила широкое распространение среди палеоантропологов. Наиболее полное исследование, посвященное физическому типу сарматского населения, было проведено Б.В. Фирштейн в 1970 году. В распоряжении исследователя было 14 посткраниальных скелетов. Из них 9 мужских и 5 женских. В результате проведенного исследования ученым был сделан вывод, что рост и вес у сарматов был средний (у женщин вес несколько меньше среднего), телосложение крепкое. Пропорции верхних и нижних конечностей среднедлинные.

В 2008 г. в рамках дипломной работы Г. Климовой было осуществлено остеологическое исследование сарматского населения Нижнего Поволжья [14]. Исследовалось 42 посткраниальных скелета, из них 20 мужских и 22 женских. В результате проведенного исследования автор пришел к выводу о том, что раннесарматская выборка характеризуется средним ростом, меоморфным телосложением, у женщин отличается широкоплечность.

В данной работе предпринята попытка проведения остеологического исследования раннесарматских материалов с территории Нижнего Поволжья. Остеологический анализ проводился по методике Мартина с использованием бланка Института этнологии и антропологии РАН (бланк 1965 г. с рекомендациями В.П. Алексеева). В работе было использовано 55 признаков стандартного бланка института этнологии и антропологии РАН, 12 из них являются указателями обозначений признаков по Р. Мартину. На основе индивидуальных данных были вычислены среднее арифметическое значение, среднеквадратичное отклонение и составлена соответствующая таблица средних значений.

Оценка абсолютных значений признаков давалась в соответствии с рубрикациями, составленными В.В. Бунаком, и представлена в работе Н.Н. Мамоновой [15] и А.Г. Тихонова [19]. Указатели сечений проанализированы с помощью рубрикации В.П. Алексеева [2]. Всего в остеологическую выборку было включено 81 мужской и 70 женских индивидов.

Остеологическая характеристика мужчин. Абсолютные значения продольных и поперечных размеров длинных костей верхних и нижних конечностей характеризуются средними категориями. При этом наибольшая длина плечевой и большеберцовой костей имеет тенденцию к удлинению. Остеологическая длина ноги $(F e m 2+T i b 2)$, по 
рубрикации В.В. Бунака [15, с. 23], малая (77,5 мм) (табл.1). Исследуемая группа отличается средней длинной, несколько выше средней массивностью большинства костей скелета. Кости предплечья как по указателю прочности, так и по указателю сечения характеризуются средней массивностью. Бедренные кости по наименьшей окружности диафиза характеризуются средней массивностью, с тенденцией к повышению. Однако указатель массивности большеберцовых костей в пределах больших значений. Кости голени с правой и с левой стороны удлинены относительно бедер. Плече-бедренный указатель достаточно большой, что, скорее всего, связано с коротким бедром в мужской группе.

Строение скелетной системы мужской части популяции позволяет утверждать, что сколько-нибудь заметная асимметрия присутствует в $60,0 \%$ случаев. Из всех условно симметричных признаков большинство составляют продольные размеры, что же касается поперечных, то на них также присутствует асимметрия, но ее указатели меньше продольных. На локтевых костях меньше всего выражена асимметрия. Наибольшей асимметрией обладают продольные размеры костей рук и ног, в первую очередь плечевые и бедренные кости. Значительная асиммметрия наблюдается на поперечных размерах верхних и нижних конечностей, в первую очередь это сагиттальные и поперечные размеры середины диафиза.
Конституциональные особенности. Длина тела у мужчин в среднем составляет 167,7 см. Размах вариаций по разным авторам: от 164,4 до 167,7 см (см. табл. 1). Наибольшие величины получаются при вычислении роста по формуле Г.Ф. Дебеца, которую он рекомендует использовать в выборках с разными пропорциями тела. Минимальные значения были получены при вычислении длины тела по формулам К. Пирсона и А. Ли. По условной рубрикации длины тела по Мартину [15, с. 23], изученная нами мужская серия характеризуется ростом выше среднего.

Остеологическая характеристика женщин. Абсолютные значения продольных размеров длинных костей представлены в женской группе в основном средними величинами. Исключением являются показатели локтевых и больших берцовых костей, которые находятся в пределах больших и очень больших величин. Остеологическая длина ноги (Fem $2+T i b 2)$, по рубрикации В.В. Бунака $[4$, с. 24], средняя - 71,2 мм (табл. 1).

Массивность женского скелета имеет средние показатели, так же как и у мужчин. Форма поперечных сечений правых локтевых костей уплощена в поперечном направлении по форме (эуроления). Форма сечений бедренных костей, как и у мужчин, заметно уплощена в сагиттальном направлении (эуримерия). Верхнее сечение больших берцовых костей не имеет специализированной формы и описывается эурикнемией.

Таблича 1

Длина тела и некоторые параметры длины отдельных сегментов тела

\begin{tabular}{|c|c|c|c|c|c|c|c|c|c|c|}
\hline \multirow{2}{*}{$\begin{array}{l}\text { Формулы для вычисления } \\
\text { конституциональных длин }\end{array}$} & \multicolumn{5}{|c|}{ Мужчины } & \multicolumn{5}{|c|}{ Женщины } \\
\hline & $n$ & $X$ & $S$ & Min & Max & $n$ & $X$ & $S$ & Min & Max \\
\hline$H 2+R 2$ & 31 & 55,4 & 2,8 & 61,2 & 48,8 & 23 & 50,3 & 1,8 & 53,6 & 47,3 \\
\hline$F 2+T 2 \times(F T)$ & 31 & 77,5 & 4,8 & 88,1 & 69,0 & 27 & 71,2 & 3,7 & 80,1 & 65,4 \\
\hline 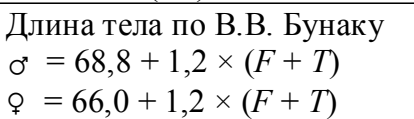 & 30 & 165,2 & 5,7 & 176,8 & 154,2 & 30 & 156,2 & 6,0 & 168,9 & 142,0 \\
\hline $\begin{array}{l}\text { Длина тела } \\
\text { по К. Пирсону и А. Ли } \\
\sigma^{*}=84,898+1,072 \times(F+T) \\
q=57,872+1,354 \times(F+T)\end{array}$ & 30 & 164,4 & 5,6 & 175,6 & 153,8 & 30 & 156,7 & 6,2 & 169,8 & 142,0 \\
\hline $\begin{array}{l}\text { Г.Ф. Дебеца: } \\
\sigma^{n}=69-4,667 \times(0,9 \times F- \\
-T-3,91)+2,244 \times F \\
o=65-4,667 \times(0,9 \times F- \\
-T-4,01)+2,244 \times F\end{array}$ & 30 & 167,7 & 6,3 & 182,7 & 158,7 & 30 & 163,2 & 9,1 & 191,9 & 150,1 \\
\hline
\end{tabular}


Асимметрия женской скелетной системы выражена, так же как и в мужской выборке, она присутствует в $60,0 \%$ случаев. Заметная асимметрия присуща продольным размерам. Наибольшей асимметрией характеризуется полная и наибольшая длина плечевой, лучевой, локтевой, бедренной кости и большой берцовой кости. Самыми асимметричными признаками во всем скелете являются параметры большой берцовой кости, где они отражены практически на всех показателях.

\section{Конституциональные особенности.}

Длина тела у женщин в среднем составила 156,2 см (см. табл. 1). Размах значений, вычисленных по формулам различных авторов, от 156,2 до 163,2 см. Изученная нами женская выборка в соответствии с рубрикацией длины тела по Мартину имеет рост выше среднего и характеризуется показателями имеющими тенденцию к увеличению роста [4, с. 24].

Анализ внутригрупповой структуpbl. Исследование внутригрупповой структуры ранних сарматов проводилось методом главных компонент. Было выделено 7 главных компонент с собственными числами больше 1,0. Суммарная дисперсия на первые три компоненты у мужчин составила $56,8 \%$ от общей внутригрупповой изменчивости, а у женщин - 55,6\%.

Вклад первой главной компоненты (далее - ГК) при анализе мужской серии - 36,9 \% от общей внутригрупповой изменчивости и женской $-34,1 \%$. Она у мужчин коррелирует с 16, у женщин с 14 остеометрическими признаками, из которых все имеют высокую положительную корреляцию.

На положительном полюсе изменчивости I ГК локализуется массивный тип, сочетающий высокий рост с длинными и массивными руками и ногами. На отрицательном полюсе находятся скелеты с низкорослым грацильным типом и с укороченными конечностями.

У мужчин II ГК составляет 12,3 \%, главные нагрузки приходятся на наибольший диаметр плечевой, а также наименьшую окружность плечевых и лучевых костей. На ІІІ ГК попадает 7,6 \%, она выделяет грацильный тип, характеризующийся малым ростом, с длинными руками и плохо развитыми продольны- ми и поперечными размерами верхних и нижних конечностей.

I ГК у женщин имеет высокие нагрузки как с размерами костей верхних конечностей (с продольными и широтными), так и с костями нижних конечностей. Максимальные положительные значения имеет высокорослый тип, у которого массивная плечевая и лучевая кость, длинные кости верхних и нижних конечностей. Максимальные значения с отрицательным знаком имеет низкорослый тип, у которого укороченные пропорции длинных костей.

II ГК обладает высокими значениями поперечного диаметра лучевой кости и луче-плечевого указателя, а также характеризуется низкорослым типом. Малые показатели имеют длины верхних и нижних конечностей.

III ГК выделяется большим берцовобедренным и луче-берцовым указателем, а также низкорослостью.

Для определения морфотипов, вероятно, существующих в исследуемой группе, была построена матрица внутригрупповых корреляций, которую обработали методом многомерного неметрического шкалирования и кластерным анализом. В результате был построен четырехпольный график и дендрограмма кластеризации.

На дендрограмме выделяются пять больших кластеров в мужской серии и три в женской. На их основе было определено несколько морфотипов, существовавших в исследуемой монопопуляции.

У мужчин первый морфотип характеризуется относительной высокорослостью, но имеет различия по абсолютным и относительным размерам верхних и нижних конечностей. Второй тип низкорослый, обладает средними показателями длины и массивности, а также малыми значениями указателей.

Третий тип у мужчин относится к категории мезаморфных типов и имеет средний рост. Четвертый тип отличается высокорослостью и грацильностью. Пятый тип характеризуется средним ростом и очень большими и массивными верхними и нижними конечностями.

Первый и третий морфотипы у женщин высокорослый и массивный, по параметрам верхних и нижних конечностей. Второй морфотип отличается низкорослостью и грацильностью, с довольно малыми указателями пропорций нижних и верхних конечностей. 
Межгрупповой анализ проводился методом главных компонент по восьми демографическим признакам. В связи с немногочисленностью цифровой информации по скелетной системе разных народов раннего железного века сравнивались 12 мужских и 8 женских групп (табл. 2).

Сравнительный материал из 12 мужских выборок раннего железного века анализировался методом главных компонент. В процессе обработки цифровой информации выдели- лись три главные компоненты с собственными числами больше 1.0 , описывающие суммарно 78,7 \% изменчивости (табл. 3).

Первая главная компонента описывает 47,9 \% общей межгрупповой изменчивости в мужских выборках. Из 10 признаков 6 имели высокую положительную корреляцию (наибольшая длина плечевой кости, наибольшая длина и наименьшая окружность лучевой кости, наибольшая длина локтевой кости, наибольшая длина бедренной и общая длина боль-

\section{Сравнительный материал}

Таблийа 2

\begin{tabular}{|c|l|l|l|}
\hline $\begin{array}{c}\text { Номер } \\
\text { серии }\end{array}$ & \multicolumn{1}{|c|}{ Название } & \multicolumn{1}{|c|}{$\begin{array}{c}\text { Археологическая } \\
\text { культура }\end{array}$} & \multicolumn{1}{|c|}{$\begin{array}{c}\text { Автор и год } \\
\text { публикации }\end{array}$} \\
\hline 1 & Нижнее Поволжье & Раннесарматская & Исследуемая серия \\
\hline 2 & Нижнее Поволжье & Позднесарматская & Климова Г.В., 2008 \\
\hline 3 & Саратовское Заволжье & Раннесарматская & Фирштейн Б.В., 1970 \\
\hline 4 & Саратовское Заволжье & Среднесарматская & Фирштейн Б.В., 1970 \\
\hline 5 & Саратовское Заволжье & Позднесарматская & Фирштейн Б.В., 1970 \\
\hline 6 & Аймырлыг ХХХІ & $\begin{array}{l}\text { Центральная Тува, } \\
\text { гунно-сарматское время }\end{array}$ & $\begin{array}{l}\text { Богданова В.И., } \\
\text { Радзюн А.Б., 1991 }\end{array}$ \\
\hline 7 & Гришкин Лог-I & Тагарская культура & Медникова М.Б., 1995 \\
\hline 8 & Сарагаш & Тагарская культура & Медникова М.Б., 1995 \\
\hline 9 & Знаменка & Тагарская культура & Медникова М.Б., 1995 \\
\hline 10 & Туран I & Тагарская культура & Медникова М.Б., 1995 \\
\hline 11 & Туран II & Тагарская культура & Медникова М.Б., 1995 \\
\hline 12 & Косасар-2 & Джетыасарская культура & Медникова М.Б., 1995 \\
\hline
\end{tabular}

Таблииа 3

Результаты межгруппового анализа выборок раннего железного века

\begin{tabular}{|l|c|c|c|c|c|c|}
\hline \multirow{2}{*}{ Признак по Мартину и др. } & \multicolumn{3}{|c|}{ Мужчины } & \multicolumn{3}{|c|}{ Женщины } \\
\cline { 2 - 7 } & 1 ГК & 2 ГК & 3 ГК & 1 ГК & 2 ГК & 3 ГК \\
\hline $\begin{array}{l}\text { Наибольшая длина пле- } \\
\text { чевой кости }\end{array}$ & 0.797 & -0.212 & -0.243 & 0.828 & -0.466 & 0.087 \\
\hline $\begin{array}{l}\text { Наименьшая окружность } \\
\text { плечевой кости }\end{array}$ & 0.435 & -0.249 & 0.600 & 0.790 & 0.271 & 0.303 \\
\hline $\begin{array}{l}\text { Наибольшая длина луче- } \\
\text { вой кости }\end{array}$ & 0.868 & 0.189 & -0.357 & 0.910 & -0.302 & -0.070 \\
\hline $\begin{array}{l}\text { Наименьшая окружность } \\
\text { лучевой кости }\end{array}$ & 0.740 & -0.486 & 0.104 & 0.202 & 0.588 & 0.741 \\
\hline $\begin{array}{l}\text { Наибольшая длина лок- } \\
\text { тевой кости }\end{array}$ & 0.900 & -0.190 & -0.187 & 0.949 & -0.129 & 0.018 \\
\hline $\begin{array}{l}\text { Наименьшая окружность } \\
\text { локтевой кости }\end{array}$ & 0.469 & -0.036 & 0.783 & 0.964 & 0.057 & 0.032 \\
\hline $\begin{array}{l}\text { Наибольшая длина бед- } \\
\text { ренной кости }\end{array}$ & 0.901 & 0.055 & -0.114 & 0.944 & -0.219 & 0.137 \\
\hline $\begin{array}{l}\text { Окружность середины } \\
\text { диафиза бедренной кости }\end{array}$ & 0.288 & 0.762 & 0.095 & 0.669 & 0.673 & -0.271 \\
\hline $\begin{array}{l}\text { Общая длина большой } \\
\text { берцовой кости }\end{array}$ & 0.839 & 0.263 & 0.013 & 0.947 & -0.222 & -0.169 \\
\hline $\begin{array}{l}\text { Наименьшая окружность } \\
\text { большой берцовой кости }\end{array}$ & 0.197 & 0.871 & 0.160 & 0.512 & 0.707 & -0.457 \\
\hline Собственные числа & 4.791 & 1.828 & 1.253 & 6.507 & 1.797 & 0.984 \\
\hline Процент дисперсии & 47.911 & 18.277 & 12.527 & 65.070 & 17.974 & 9.844 \\
\hline
\end{tabular}


шой берцовой костей). Первая компонента разграничивает на полюсах изменчивости 2 типа: один тип сочетает удлиненные продольные размеры костей при большом значении окружности лучевой кости; второй вариант предполагает альтернативное сочетание пропорций тела, то есть укороченные продольные размеры костей при малом значении окружности лучевой кости.

На положительном полюсе межгрупповой изменчивости находятся следующие группы: Косасар-2 и три тагарские группы (Сарагаш, Знаменка, Туран II), а также ранние сарматы Саратовского Заволжья. Отрицательный полюс объединил ранних сарматов Нижнего Поволжья, Аймырлыга XXXI, тагарские серии - Гришкин Лог и Туран I. Поздние сарматы Нижнего Поволжья, средние и поздние сарматы Саратовского Заволжья также имеют отрицательное значение больше -0.600 .

Вторая главная компонента описывает 18,2 \% межгрупповой изменчивости. Она имеет 2 признака со значимой положительной корреляцией (окружность середины диафиза бедренной и наименьшая окружность большой берцовой костей). Из этого следует, что вторая главная компонента определила следующие крайние варианты: 1) вариант имеет усиленную массивность нижних конечностей и 2) вариант имеет грацильные нижние конечности.

При учете второй компоненты на положительном полюсе межгрупповой изменчивости оказались ранние сарматы Саратовского Заволжья, Аймырлыг и тагарская серия - Туран I, а на отрицательном: сарматы поздние и ранние Нижнего Поволжья, средние и поздние сарматы Саратовского Заволжья, а также тагарские серии.

Третья компонента описывает $12,5 \%$ изменчивости, и два признака имеют значимую положительную корреляцию (наименьшая окружность плечевой и локтевой костей). Она разграничивает варианты с массивным и грацильным строением верхних конечностей.Таким образом, третья компонента объединила ранних сарматов Нижнего Поволжья и поздних сармат Саратовского Заволжья, группу из Косасара-2, тагарцев - Туран I и Туран II как серии с массивными верхними конечностями. Альтернативное строение плечевой и локтевой костей имеют поздние сарматы Нижнего Поволжья и ранние сарматы Саратовского Заволжья, группа Аймырлыга и следующие выборки тагарцев: Гришкин Лог, Сарагаш и Знаменка.

При анализе главных компонент остеометрических признаков 9 женских серий эпохи раннего железного века первые три главные компоненты с собственными числами больше 1.0 описали 92,7 \% межгрупповой изменчивости (см. табл. 3). Первая главная компонента разграничила на полюсах межгрупповой изменчивости 2 типа: первый сочетает большие продольные размеры костей верхних и нижних конечностей и большие значения охватных размеров плечевой, локтевой и бедренных костей. Второй тип ему противоположен: при малых величинах продольных размеров костей конечностей небольшие значения наименьшей окружности плечевой и локтевой, окружности середины диафиза бедренной костей.

Первая главная компонента разграничивает, с одной стороны, группу тагарцев (Сарагаш, Знаменка,Туран II), а с другой - ранних и поздних сарматов Нижнего Поволжья, Аймырлыга, Косасара-2, Гришкиного Лога I.

Вторая главная компонента описывает 17,9 \% межгрупповой изменчивости и выделяет 2 типа: с большими и маленькими обхватами нижних конечностей. В группу с массивными лучевыми, бедренными и большими берцовыми костями вошли ранние и поздние сарматы Нижнего Поволжья, тагарцы из Турана II и группа из Аймырлыга. Противоположным типом оказались серии Косасара-2, Сарагаша и Гришкиного Лога I.

Третья компонента описывает всего 9,8 \% межгрупповой изменчивости . Она разграничивает серии с массивными и грацильными лучевыми костями. На положительном полюсе изменчивости по этой компоненте оказались поздние сарматы Нижнего Поволжья, выборка из Аймырлыга, тагарцы Знаменки и Туран I. На отрицательном - ранние сарматы Нижнего Поволжья, группы из Косасара-2, Турана II и Знаменки.

Кроме анализа переменных главных компонент, матрица межгрупповых корреляций обрабатывалась кластерным методом и многомерным неметрическим шкалированием (см. рис.1-4). 


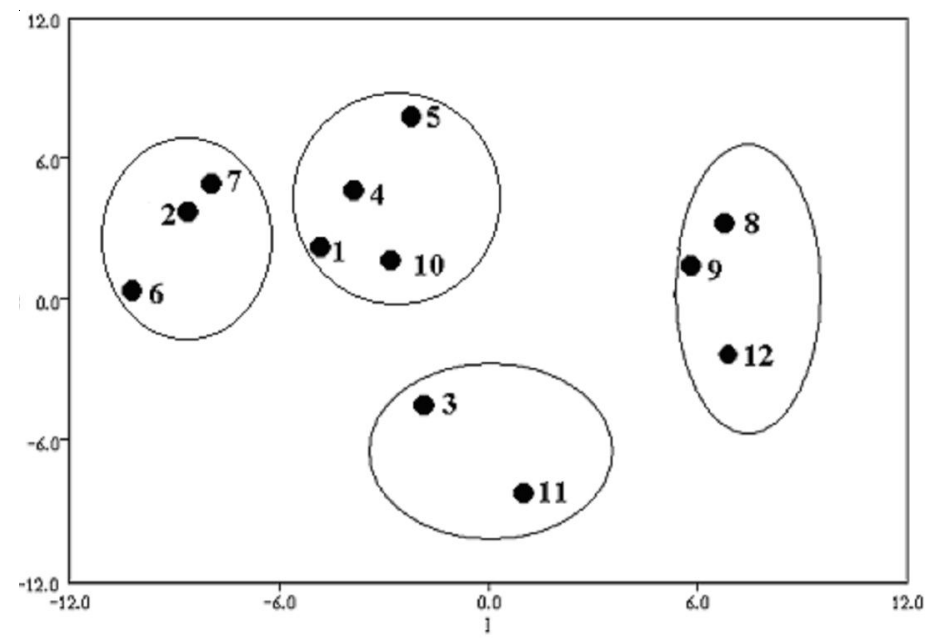

Рис. 1. Результаты неметрического многомерного шкалирования мужских выборок раннего железного века:

1 - ранние сарматы Нижнего Поволжья; 2 - поздние сарматы Нижнего Поволжья;

3 - ранние сарматы Саратовского Заволжья; 4 - средние сарматы Саратовского Заволжья; 5 - поздние сарматы Саратовского Заволжья; 6 - Аймырлыг; 7 - Гришкин Лог I; 8 - Сарагаш; 9 - Знаменка; 10 -Туран I; 11 - Туран II; 12 - Косасар-2

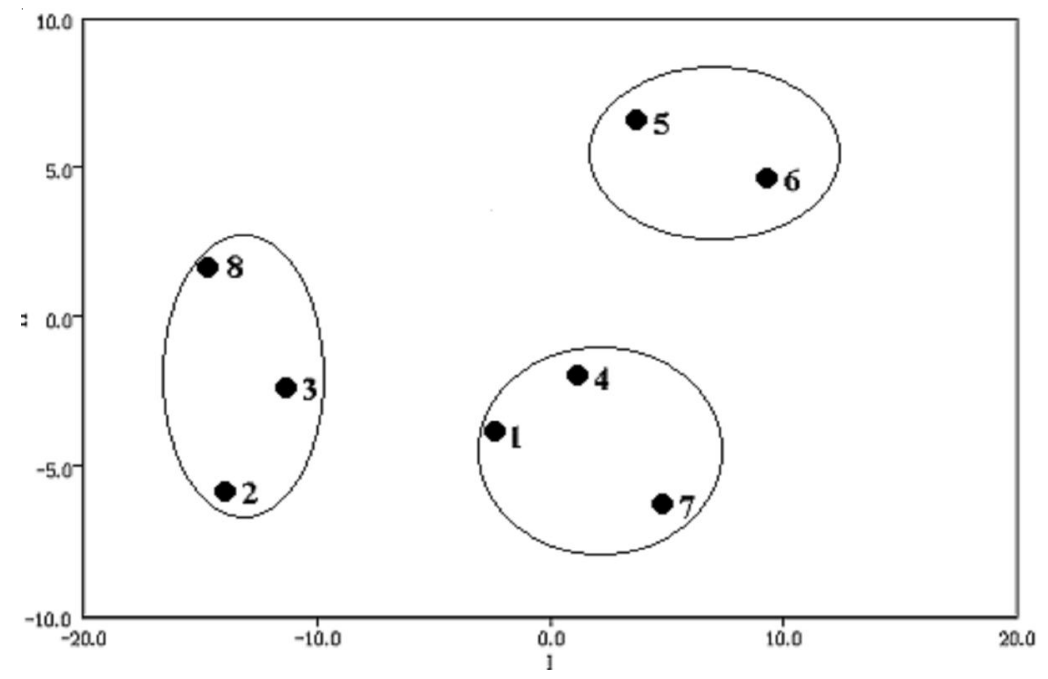

Рис. 2. Результаты неметрического многомерного шкалирования мужских выборок раннего железного века:

1 - ранние сарматы Нижнего Поволжья; 2 - поздние сарматы Нижнего Поволжья; 3 - Аймырлыг; 4 - Гришкин Лог I; 5 - Сарагаш; 6 - Знаменка; 7 - Туран II; 8 - Косасар-2

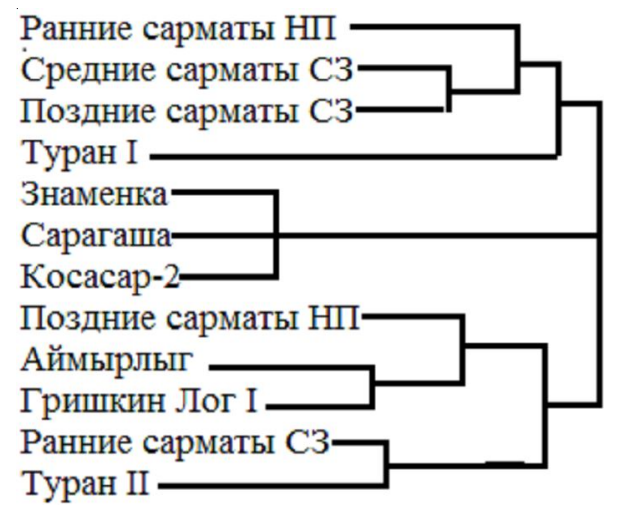

Рис. 3. Итоги кластерного анализа мужских серий 


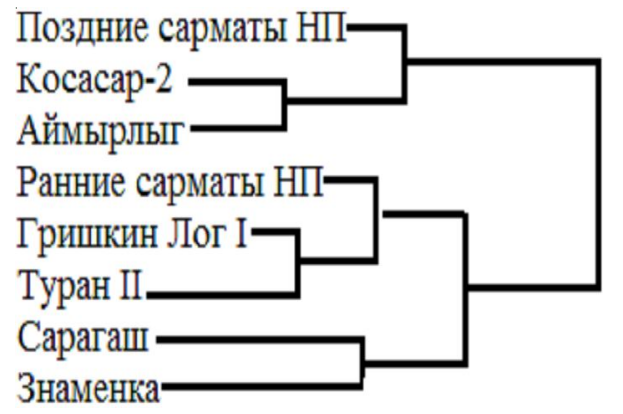

Рис. 4. Итоги кластерного анализа женской серии

Результаты обоих анализов мужских серий показывают четыре скопления групп. Первое скопление образовали три сарматские группы (средние и поздние сарматы Саратовского Заволжья, ранние сарматы Нижнего Поволжья), к ним присоседилась группа тагарцев из Туран I. Тяготение среднесарматской выборки Саратовского Заволжья к позднесарматским вполне объяснимо, так как по краниологическим признакам прослеживается их частичное генетическое сходство. Второе скопление групп включает две тагарские серии из Знаменки и Сарагаша и серию джетыасарской культуры из Косасара-2. Третье скопление объединило в себе группы поздних сарматов Нижнего Поволжья, а также две группы Аймырлыга и Гришкиного Лога I. Последняя четвертая группа состоит из выборок ранних сармат Саратовского Заволжья и Турана II.

Аналогичный анализ женских групп продемонстрировал три скопления: первое включает серии поздних сарматов Нижнего Поволжья, джетыасарскую группу из Косасара-2 и серию из Аймырлыга. Второе скопление состоит из серии ранних сарматов Нижнего Поволжья и тагарской выборки из Гришкиного Лога I и Турана II. Третья группа включает в себя серии из тагарской культуры Сарагаша и Знаменки.

Таким образом, разнополые группы ранних сармат Нижнего Поволжья имеют следующие характеристики: абсолютные значения поперечных размеров у мужчин и женщин ранних сарматов характеризуются в целом средними значениями, которые имеют показатели к удлинению. Продольные показатели у мужчин и женщин тяготеют к большим величинам. Остеологическая длина ноги для гендерных групп укладывается в малые величины у мужчин и в средние у женщин. Асимметрия скелетной системы свойственна обеим разнополым группам, у мужчин она отчетливо выражается на бедренных костях, а у женщин на больших берцовых костях. Отмечен значительный половой диморфизм в исследованной серии. Исследуемая выборка, как мужская, так и женская, характеризуется ростом выше среднего. Серия ранних сармат Нижнего Поволжья обладает внутригрупповой неоднородностью, выделяется пять мужских и три женских морфотипа. У мужчин преобладает высокорослый, мезоморфный тип телосложения, а для женщин характерен тип, имеющий средний рост и массивность.

Ранние сарматы имеют локальные различия, что подтверждается на примере серий из Волго-Донского междуречья и Заволжья. Рассмотрев исследуемую выборку на межгрупповом уровне, удалось установить, что раннесарматская серия тяготеет к южносибирским популяциям раннего железного века. Объединение ранних сармат Нижнего Поволжья с группой тагарцев, а также со средними и поздними сарматами Саратовского Заволжья тоже вполне объяснимо, так как и по краниологическим признакам прослеживается их частичное генетическое сходство. Раннесарматские серии тяготеют к южносибирским выборкам раннего железного века, что дает дополнительное основание предполагать истоки раннесарматского населения. Результаты исследования системы остеометрических признаков по раннесарматским группам вполне соотносятся с проведенными отечественными учеными краниологическими исследованиями, тем самым подтверждая миграционную концепцию происхождения сарматов. 


\section{ПРИМЕЧАНИЯ}

1 Работа выполнена при поддержке гранта № 15-01 00063a «Палеопатология сарматского населения Южнорусских степей».

\section{СПИСОК ЛИТЕРАТУРЫ}

1. Акимова, М. С. Антропология древнего населения Приуралья / М. С. Акимова - М. : Наука, 1968. -120 c.

2. Алексеев, В. П. Остеометрия: методика антропологических исследований / В. П. Алексеев. М. : Наука, 1966. - 249 с.

3. Балабанова, М. А. Антропологический состав и происхождение раннесарматского населения Южного Приуралья и Нижнего Поволжья / М. А. Балабанова // Раннесарматская культура: формирование, развитие, хронология : материалы IV Междунар. конф. «Проблемы сарматской археологии и истории». - Самара: СНЦРАН, 2000. - Вып. I. -C. 105-116.

4. Балабанова, М. А. Антропология древнего населения Южного Приуралья и Нижнего Поволжья. Ранний железный век / М. А. Балабанова. М. : Наука, 2000. - 132 с.

5. Балабанова, М. А. Краниология сарматских погребальных памятников IV-III вв. до н. э. / М. А. Балабанова // НАВ. - 1999. - Вып. 2. - С. 55-72.

6. Балабанова, М. А. Методика палеоантропологических исследований : учеб.-метод. пособие / М. А. Балабанова. - Волгоград : Изд-во ВолГУ, 1998. - 84 c.

7. Балабанова, М. А. О древних макрокефалах Восточной Европы / М. А. Балабанова // OPUS: междисциплинарные исследования в археологии. 2004. - № 3. - С. 171-187.

8. Батиева, Е. Ф. Черепа из курганов междуречья Маныча и Сала (сарматское время) / Л. С. Ильюков, М. В. Власкин // Сарматы междуречья Сала и Маныча. - Ростов н /Д. : Изд-во РГУ, 1992. - Вып. І. C. 262-271.

9. Богданова, В. И. Палеоантропологический материал гунно-сарматского времени из Центральной Тувы / В. И. Богданова, А. Б. Радзюн // Новые коллекции и исследования по антропологии и археологии. - СПб. : Наука, 1991. - Вып. XLIV. - С. 55-100.

10. Бунак, В. В. Соотношение длины сегментоав и полная длина тела по измерениям на скелетах (сравнительная характеристика двух групп) / В. В. Бунак // Вопросы антропологии. - 1961.-Вып. 7. -С. 41-65.

11. Гинзбург, В. В. Этнические связи древнего населения / В. В. Гинзбург // МИА. - 1959. - № 60. C. 563-575.

12. Дебец, Г. Ф. Палеоантропология СССР / Г. Ф. Дебец // ТИЭ. - 1948. - Т. 4. - 392 с.
13. Дерябин, В. Е. Построение типологии пропорций тела методом главных компонент / В. Е. Дерябин // Проблемы эволюционной морфологии человека и его рас. - М. : Наука, 1986. - С. 78-83.

14. Климова, Г. В. Сходства и различия сарматского населения раннего и позднего периодов по антропологическим данным. К обоснованию миграционной концепции : [дипломная работа] / Г. В. Климова. -2008. - 95 с.

15. Мамонова, Н. Н. Опыт применения таблиц В.В. Бунака при разработке остеометрических материалов / Н. Н. Мамонова // Проблемы эволюционной морфологии человека и его рас. - М. : Наука, 1986. - С. 21-23.

16. Медникова, М. Б. Древние скотоводы Южной Сибири: палеоэкологическая реконструкция по данным антропологии / М. Б. Медникова. - М., 1995. $-216 \mathrm{c}$.

17. Перерва, Е. В. Население сарматской эпохи по антропологическим материалам из могильников Нижнего Поволжья и Нижнего Дона : автореф. дис. ... канд. ист. наук / Перерва Евгений Владимирович. - М., 2005. - $26 \mathrm{c.}$

18. Руденко, С. И. Описание скелетов из прохоровских курганов / С. И. Руденко // Курганные находки Оренбургской области эпохи раннего и позднего эллинизма. - Пгр., 1918. - С. 2-12.

19. Тихонов, А. Г. Физический тип средневекового населения Евразии по данным остеологии : автореф. дис. ... канд. ист. наук / Тихонов Алексей Геннадьевич. - М, 1997. - 36 с.

20. Фирштейн, Б. В. Сарматы Нижнего Поволжья в антропологическом освещении / Б. В. Фирштейн // Антропологические данные к вопросу о великом переселении народов. Авары и Сарматы. Л. : Наука, 1970. - С. 69-201.

\section{REFERENCES}

1. Akimova M.S. Antropologiya drevnego naseleniya Priuralya [The Anthropology of Ancient Population of the Urals]. Moscow, Nauka Publ., 1968. $120 \mathrm{p}$.

2. Alekseev V.P. Osteometriya: Metodika antropologicheskikh issledovaniy [Osteometry: The Technique of Anthropological Research]. Moscow, Nauka Publ., 1966. 249 p.

3. Balabanova M.A. Antropologicheskiy sostav i proiskhozhdenie rannesarmatskogo naseleniya Yuzhnogo Priuralya i Nizhnego Povolzhya [The Anthropological Composition and Origin of the Early Sarmatian Population of the Southern Urals and the Lower Volga Region]. Rannesarmatskaya kultura: formirovanie, razvitie, khronologiya. Materialy IV mezhdunarodnoy konferentsii "Problemy sarmatskoy 
arkheologii i istorii" [The Early Sarmatian Culture: formation. Development, and chronology. Proceedings of the 4th International Conference "Issues of Sarmatian Archaeology and History"]. Samara, 2000, iss. 1, pp. 105-116.

4. Balabanova M.A. Antropologiya drevnego naseleniya Yuzhnogo Priuralya $i$ Nizhnego Povolzhya. Ranniy zheleznyy vek [The Anthropology of Ancient Population of the Southern Urals and the Lower Volga Region. Early Iron Age]. Moscow, Nauka Publ., 2000. 132 p.

5. Balabanova M.A. Kraniologiya sarmatskikh pogrebalnykh pamyatnikov IV-III vv. do n.e. [The Craniology of Sarmatian Burial Monuments of the 4th3rd Centuries B.C.]. Nizhnevolzhskiy arkheologicheskiy vestnik, 1999, no. 2, pp. 55-72.

6. Balabanova M.A. Metodika paleoantropologicheskikh issledovaniy: Uchebnometodicheskoe posobie [The Methods of PaleoAnthropological Research: Teaching Tutorial]. Volgograd, Izd-vo VolGU, 1998. 84 p.

7. Balabanova M.A. O drevnikh makrokefalakh Vostochnoy Evropy [On Ancient Makrokephales of Eastern Europe]. OPUS: mezhdistsiplinarnye issledovaniya $v$ arkheologii, 2004, no. 3, pp. 171-187.

8. Batieva E.F., Ilyukov L.S., Vlaskin M.V. Cherepa iz kurganov mezhdurechya Manycha i Sala (sarmatskoe vremya) [Skulls From Burial Grounds Located in the Interfluve of the Manych River and the Sal River (Sarmatian Time)]. Sarmaty mezhdurechyya Sala i Manycha [The Sarmatian Tribes From the Interfluve Area of the Manych River and the Sal River]. Rostov-on-Don, 1992, iss. pp. 262-271.

9. Bogdanova V.I., Radzyun A.B. Paleoantropologicheskiy material gunnosarmatskogo vremeni iz Tsentralnoy Tuvy [PaleoAnthropological Material of the Hunno-Sarmatian Time From Central Tuva]. Novye kollektsii $i$ issledovaniya po antropologii $i$ arkheologii. Sbornik materialov po arkheologii i etnografii [New Collections and Research in Anthropology and Archaeology. Collected Materials on Archeology and Etnography]. Saint Petersburg, 1991, vol. XLIV, pp. 55-100.

10. Bunak V.V. Sootnoshenie dliny segmentov i polnaya dlina tela po izmereniyam na skeletakh (sravnitelnaya kharakteristika dvukh grupp) [The Ratio of the Length of Segments and the Total Body Length According to the Measurements of Skeletons (Comparative Characteristics of Two Groups)]. Voprosy antropologii, 1961, iss. 7, pp. 41-65.

11. Ginzburg V.V. Etnicheskie svyazi drevnego naseleniya [The Ethnic Connections of the Ancient Population]. Materialy $i$ issledovaniya po arkheologii, 1959, no. 60, pp. 563-575.
12. Debets G.F. Paleoantropologiya SSSR [Paleoanthropology of the USSR]. Trudy Instituta etnografii ANSSSR, 1948, vol. 4. 392 p.

13. Deryabin V.E. Postroenie tipologii proportsiy tela metodom glavnykh komponent [Building a Typology of Body Proportions by the Method of Principal Components]. Problemy evolutsionnoy morfologii cheloveka $i$ ego ras [The Problems of Evolutionary Morphology of the Human and Human Race]. Moscow, Nauka Publ., 1986, pp. 78-83.

14. Klimova M.G. Skhodstva i razlichiya sarmatskogo naseleniya rannego i pozdnego periodov po antropologicheskim dannym. Kobosnovaniyu migratsionnoy kontseptsii. Thesis [Similarities and Differences of the Sarmatian Population of Early and Late Periods Based on Anthropological Data. On the Justification of the Concept of Migration. Thesis]. 2008. 95 p.

15. Mamonova N.N. Opyt primeneniya tablits V.V. Bunaka pri razrabotke osteometricheskikh materialov [The Experience ofUsing V.V.Bunak's Tables in the Development of Osteometry Materials]. Problemy evolutsionnoy morfologii cheloveka $i$ ego ras [The Problems of Evolutionary Morphology of the Human and Human Race]. Moscow, Nauka Publ., 1986, pp. 21-33.

16. Mednikova M.B. Drevnie skotovody Yuzhnoy Sibiri: paleoekologicheskaya rekonstruktsiya po dannym antropologii [The Ancient Cattle Farmers of Southern Siberia: Paleo-Ecological Reconstruction According to Anthropologic Data]. Moscow, 1995.216p.

17. Pererva E.V. Naselenie sarmatskoy epokhi po antropologicheskim materialam iz mogilnikov Nizhnego Povolzhya i Nizhnego Dona: avtoref. dis. kand. ist. nauk [The Population of Sarmatian Era According to the Anthropological Data From the Burial Grounds of the Lower Volga Region and the Lower Don Regions. Cand. hist. sci. abs. diss.]. Moscow, 2005. 26 p.

18. Rudenko S.I. Opisanie skeletov iz prokhorovskikh kurganov [Description of Skeletons From the Prokhorov's Mounds]. Kurgannye nakhodki Orenburgskoy oblasti epokhi rannego i pozdnego ellinizma [Mound Findings From the Orenburg Region of the Early and Late Hellenistic Age]. Petrograd, 1918, pp. 2-12.

19. Tikhonov A.G. Fizicheskiy tip srednevekovogo naseleniya Evrazii po dannym osteologii: avtoref. dis. kand. ist. nauk [The Physical Type of the Population in Medieval Eurasia According to Osteologic Data. Cand. hist. sci. abs. diss.]. Moscow. 1997. 36 p.

20. Firshteyn B.V. Sarmaty Nizhnego Povolzhya v antropologicheskom osveshchenii [The Sarmatians of the Lower Volga Region in the Anthropology]. Antropologicheskie dannye: $k$ voprosu o velikom pereselenii narodov. Avary i sarmaty [Anthropological Data: to the Issue of the Great Migration. Avars and Sarmatians]. Leningrad, Nauka Publ., 1970, pp. 69-201. 